\title{
On the Territorial Organisation of Early Medieval Hampshire
}

\author{
Stuart Brookes
}

Barbara Yorke's typically incisive work, integrating historical and archaeological approaches, has to me always demonstrated most clearly the value of adopting a multi-disciplinary approach. Her willingness to include archaeological evidence alongside that from written sources has facilitated the analysis of Anglo-Saxon England, and Wessex in particular, in a way that provides insights of equal relevance to those who study the social, cultural, historical, or landscape dimensions of early medieval societies. Barbara's interest in multi-disciplinarity has seen her form a long and fruitful collaboration with archaeologists at UCL, co-investigating on a number of research projects. It is through my work on two of these projects - Landscapes of Governance and Travel and Communication in Anglo-Saxon England ${ }^{1}$ - that I first properly got to known her.

Drawing on aspects of research that emerged from these projects, this paper reviews the evidence for the political geography of early Hampshire - an area so well known to Barbara. The recent identification in Hampshire of a number of early territories underlying the later configuration of administrative divisions allows for a more detailed examination of the internal organisation of early medieval kingdoms. ${ }^{2}$ This paper makes observations about the suggested 'small shires' of Hampshire and describes some of the features of these early territories. It is argued that different types of territories can be identified, the comparison of which throws light on the evolution of local districts and of early Anglo-Saxon kingdoms.

\section{'Folk' Territories and Meeting-places in Anglo-Saxon England}

Landscape archaeologists and historians have suggested the existence of a number of early territorial entities - larger than the hundred but smaller than

$1<$ www.ucl.ac.uk/archaeology/research/projects/assembly>; <www.ucl.ac.uk/archaeology/ research/directory/travel-communication-anglo-saxon-england>. (Accessed Dec. 2019).

2 Bruce Eagles, 'Small Shires' and Regiones in Hampshire and the Formation of the Shires of Eastern Wessex," ASSAH 19 (2015), 122-52. 
the shire as recorded in Domesday Book - that can be reconstructed from place-names, historical and archaeological evidence. Perhaps the most widely known of these is that of the Hropingas in Essex. ${ }^{3}$ The extent of this putative 'folk' grouping - the land of 'Hroða's people' — is argued to be represented by an adjoining cluster of eight parishes all of which are named Roding lying either side of the River Roding and extending to the watershed of the river basin. Significantly, the existence of this territory appears to belong to a chronological horizon predating the administrative geography recorded in Domesday Book - by 1086 the Roding parishes lay in two different hundreds (Dunmow and Ongar), neither of which preserves the name of the Hropingas. ${ }^{4}$

In some cases these putative territories can be related to terms occurring in early medieval sources. A charter of $c .706 \times 709$ by Swæfred, king of Essex, to Ingwald, bishop of London, granted land in Deningei, Essex, ${ }^{5}$ a 'district' R.E. Zachrisson believes on etymological grounds to have included the Dengie peninsula along with Danbury and the forest of Danegris near Chelmsford, and belonging to the Drenningas-folk. ${ }^{6}$ Similar districts in Kent appear to be fossilised by the time of the Domesday survey as 'lathes' (singular OE lceð). Each lathe comprised several smaller divisions-hundreds-and formed in turn the administrative subdivisions of the shire. ${ }^{7}$

Territorial entities similar to the lathe or the district of the Dcenningas are probably what are referred to in earlier sources in Latin as regiones or provincice. ${ }^{8}$ In his brief, but incisive discussion of these terms and their use in Bede's

Steven Bassett, "In Search of the Origins of Anglo-Saxon Kingdoms," in The Origins of Anglo-Saxon Kingdoms, ed. Steven Bassett (Leicester, 1989), pp. 3-27, at pp. 21-23, Fig. 1.11; Bassett, "Continuity and Fission in the Anglo-Saxon Landscape: The Origins of the Rodings (Essex)," Landscape History 19 (1997), 25-42.

$4 \quad$ P.H. Reaney, Place-Names of Essex (Cambridge, 1935), map of hundreds and parishes.

$5 \quad \mathrm{~S} 1787$.

6 R.E. Zachrisson, "OE deen (n) M Dutch dan, and the Name of Danmark," Acta Philologica Scandinavica 1 (1926-1927), 284-92, at pp. 284, 286; Reaney, Place-Names of Essex, pp. 213-4.

7 J.E.A. Jolliffe, Pre-Feudal England: The Jutes (London, 1933), pp. 39-41; Nicholas Brooks, "The Creation and Early Structure of the Kingdom of Kent," in Origins of Anglo-Saxon Kingdoms, ed. Bassett, pp. 55-74, at p. 69; Stuart Brookes, "The Lathes of Kent: A Review of the Evidence," in Studies in Early Anglo-Saxon Art and Archaeology: Papers in Honour of Martin G. Welch, ed. Stuart Brookes, Sue Harrington, and Andrew Reynolds, BAR Brit. Ser. 527 (Oxford, 2011), pp. 156-70.

8 E.g. Bede $H E$ II.14, III.20, IV.13, IV.19, V.19; discussed by Barbara Yorke, Wessex in the Early Middle Ages (Leicester, 1995), pp. 39-43. Indeed, the equivalence of these terms is sometimes made explicit: the East Kent lathe of St Augustine (Lest'de scō Augustine in the 1240 Assize Roll: Paul Cullen, "The Place-Names of the Lathes of St Augustine and Shipway, Kent" Unpublished PhD Thesis, 2 vols (University of Sussex, 1997), 1:289) was referred to in an original late 8th-century charter as regione Eastrgena (S 128). 
Ecclesiastical History James Campbell makes several important observations. ${ }^{9}$ Of the two terms, provincia appears to denote larger entities. At times, Bede uses it to describe kingdoms, and at others makes clear that such kingdoms contained smaller regiones..$^{10}$ It seems likely that provincice, at least, reflected some form of supra-local group affiliation. Some are mentioned as having a gens (a 'people') or a rex ('king'), implying a degree of political coherence and autonomy. They may on occasion have been relatively well defined. Both regiones and provincice are often named with reference to geographical features such as rivers or important central places, and are co-areal with geographical basins defined by watersheds. For example Bede refers to the Meanuarorum prouinciam, "the territory of the dwellers of the (River) Meon."11 Similarly, the interpolated but basically authentic 7 th-century foundation charter of Chertsey abbey, grants lands that go to the terminum alterius prouincie que apellatur Sunninges, "boundary of another provincia which is called [after the] followers of Sunna,"12 and other districts also had clear unambiguous boundaries. ${ }^{13}$

While regiones seem to be smaller in size than provincice these might also have originated as self-identifying groups of people, or 'folk', rather than necessarily as administrative divisions of kingdoms. ${ }^{14}$ The lands of the Girvii, Loidis, Incuneningum and Infeppingum are referred to by Bede as regiones. ${ }^{15}$ In keeping, several of the lathes, in their earliest forms in Domesday Book, are compounded with the $\mathrm{OE}$ community-name element ware. ${ }^{16}$ For example, we come across Burhwaralced, referring to the "district of the men of the stronghold," i.e. Canterbury; Limenwaralced, 'district of the men of the Limen'; Wiwaralced 'district of the men of Wye.' ${ }^{17}$ That is not to say that these districts might not also be fossilised in later administrative geography. Indeed, many authors have successfully argued that some of the boundaries of later hundreds, pre-Conquest estates and parishes, preserve—at least in part-the

9 James Campbell, Bede's Reges and Principes, Jarrow Lecture (Jarrow, 1979).

10 Campbell, Bede's Reges and Principes, pp. 3-4.

11 Bede $H E$ iv.13.

12 S 1165.

13 Stuart Brookes and Andrew Reynolds, "Territoriality and Social Stratification: The Relationship between Neighbourhood and Polity in Anglo-Saxon England," in Polity and Neighbourhood in Early Medieval Europe, ed. Julio Escalona, Orri Vésteinsson and Stuart Brookes (Turnout, 2019), pp. 267-303.

14 Cf. also F.M. Stenton, Anglo-Saxon England. 3rd ed. (Oxford, 1971), p. 293; John Blair, "Frithuwold's Kingdom and the Origins of Surrey," in Origins of Anglo-Saxon Kingdoms, ed. Bassett, pp. 97-105, at p. 105; Stephen Rippon, Making Sense of an Historic Landscape (Oxford, 2012), pp. 186-91.

15 Campbell Bede's Reges and Principes, pp. 3-4.

16 A.H. Smith, English Place-name Elements, 2 parts (Cambridge, 1956), 2:246.

17 Brooks, "Creation and Early Structure"; Brookes, "The lathes of Kent." 
outlines of these earlier territories. ${ }^{18}$ Nor does this mean the provincice or regiones alluded to by Bede were not also for administrative purposes. A probable 8th-century charter concerning the dues liable for the maintenance of Rochester Bridge corresponds closely to the Domesday lathe of Aylesford. ${ }^{19}$

Despite their connection with groups of people, nevertheless, it seems that some reconstructed regiones may have been considered as subdivisions of larger political entities from their earliest conception. In Kent, the eastern kingdom appears to have consisted of three or four districts later formalised as the lathes of Borough, Eastry, Limen, and Wye. ${ }^{20}$ Each of these districts is already suggested by the pattern of early Anglo-Saxon burials of the $5^{\text {th }}$ to $7^{\text {th }}$ centuries. ${ }^{21}$ They were also all centred on a royal vill containing the OE place-name element $-g \bar{e}$, 'district', cognate with the German $-g a u,{ }^{22}$ and which archaeological evidence suggests may already have had high-status functions by the later 6th century. ${ }^{23}$ It is, therefore, unlikely that they were ever regarded as fully autonomous units. The ruling Oiscingas - as Barbara herself has shownexerted significant power over eastern Kent already in the 6th century, and it seems probable that these eastern lathes always formed a single larger agglomeration, perhaps equivalent to the original Kentish kingdom. ${ }^{24}$

In some cases, there may therefore be a considerable blurring between regiones originating as semi-autonomous 'folk' territories and administrative districts imposed from above and identified by their community-name

18 e.g. Brooks, "Creation and Early Structure," pp. 21-3; Steven Bassett, "Boundaries of Knowledge: Mapping the Land Units of Late Anglo-Saxon and Norman England," in People and Space in the Middle Ages, 300-130o, ed. Wendy Davies, Guy Halsall, and Andrew Reynolds (Turnhout, 2007), pp. 115-42; Rippon Making Sense, pp. 151-64; Eagles, "'Small Shires' and Regiones."

19 S 1481d; Nicholas Brooks, "Rochester Bridge, AD 43-1381," in Traffic and Politics: The Construction and Management of Rochester Bridge, AD 43-1993, ed. Nigel Yates and James M. Gibson (Woodbridge, 1993), pp. 1-40.

20 Jolliffe, Pre-Feudal England.

21 Brookes, "The Lathes of Kent"; Tania Dickinson, "The Formation of a Folk District in the Kingdom of Kent: Eastry and its Early Anglo-Saxon Archaeology," in Sense of Place in Anglo-Saxon England, ed. Richard Jones and Sarah Semple (Donington, 2012), pp. 147-67.

22 Smith, English Place-name Elements, 1:82; S.E.C. Hawkes, "Anglo-Saxon Kent c. 425-725," in Archaeology in Kent to 150o, P.E. Leach, СвA Research Report 48 (London, 1982), pp. $64-78$.

23 Gabor Thomas, "Life Before the Minster: The Social Dynamics of Monastic Foundation at Anglo-Saxon Lyminge, Kent," Ant J 93 (2013), 109-45.

24 Barbara Yorke, "Joint Kingship in Kent c.56o to 785" Archaeologia Cantiana 99 (1983), 1-19; Brooks, "Creation and Early Structure." 
in -ingas, $-s \bar{e} t a$, and the like. ${ }^{25}$ This observation has some relevance to our understanding of the many entities recorded in the list known as the "Tribal Hidage.' ${ }^{26}$ In Steven Bassett's influential discussion of the political context of this source, each of these 'tribes' is regarded as a structurally similar sociopolitical unit, differing from its neighbours only in the scale of its constituent community and the authority wielded by its leader. ${ }^{27}$ However, the example of Kent suggests that, while political dominance rested in part on the control of community networks, there was also some innovation in administrative organisation. Unlike the eastern lathes, those in western Kent, and extending as putative territories into Surrey, ${ }^{28}$ are likely to have been artificial constructs that, while sympathetic to social and economic constraints of the landscape, were nevertheless created primarily to serve administrative expediency. In John Blair's assessment of the Surrey evidence such territories were being laid out already in the late 7 th century. ${ }^{29}$

One clue to discriminating between these two types of district may be their size. Rippon suggests early 'folk' territories typically cover $250-400 \mathrm{sq} . \mathrm{km} .{ }^{30}$ A similar comparison shows the size of the east Kentish lathes to be significantly larger than the territories of the Rothingas and Stoppingas, that are only 48 and 82 sq. $\mathrm{km}$ respectively. ${ }^{31}$ The latter are unlikely, therefore to represent petty kingdoms, nor probably autonomous 'tribal' units at all, but rather relatively local groupings that were always part of some larger political entity. In addition to the scale of territories one might also compare their spatial regularity. In size and form, the lathes of western Kent and the early districts of Surrey are noticeably more regular than their eastern Kent counterparts. ${ }^{32}$

Yet another clue to the structure of these districts can come from an analysis of the assembly places within and between them. Public assemblies were at the heart of Anglo-Saxon social, judicial, and administrative organisation, and it is likely that any supra-local group regularly converged on a meeting-place to settle disputes, regulate social interactions and execute legislative decrees. ${ }^{33}$ These meeting-places, like the territories of which they were part, are also

25 Cf. particularly on this point John Baker, "Old English sāte and the Historical Significance of 'Folk'-names," EME 25:4 (2017), 417-42.

26 Campbell, Bede's Reges and Principes, pp. 6-7.

27 Bassett, "In Search of the Origins."

28 Blair, "Frithuwold's Kingdom," p. 99; John Blair, Early Medieval Surrey (Stroud, 1991), pp. 22-24.

29 Blair, Early Medieval Surrey, passim.

$30 \quad$ Rippon Making Sense, p. 151.

31 Bassett, "In Search of the Origins"; Bassett, "Boundaries of Knowledge."

32 e.g. Blair, "Frithuwold's kingdom," p. 99, Fig. 7.1.

33 In his The Origins of Political Order (London, 2011), Francis Fukuyama makes the important point that mechanisms for settling disputes existed in all tribal-level societies. 
sometimes preserved in later sources. ${ }^{34}$ Particularly important in this regard are the meeting-places of Domesday hundreds, which at least by the 1oth century were used on a four-weekly basis. ${ }^{35}$

The locations of these hundred meeting-places are, on the face of it, relatively easy to identify, as many hundreds were apparently named from the site at which meetings took place. Evingar hundred in north-west Hampshire, for instance appears to have met in a field (OE efen 'even, level' + gāra 'triangular piece of land') c.1.5 km north-west of Whitchurch on high ground near a crossroad of the Harroway, named as (on) Geapan garan in the charter bounds of Whitchurch (S 378), and still known in 1650 as Evingdale. ${ }^{36}$ Clear identifications of this type are not invariably to be expected, and are not always straightforward. In some cases the feature that gave its name to a hundred-such as a tree, mound, or stone-has since disappeared or ceased to be known by that name, so the name of the hundred has effectively disappeared on the ground, along with the best means of securely identifying its meeting-place. Such is the case with the 'MAEGEN's Barrow' that gave its name to Mainsborough hundred (Maneberge, Manesberg hvnd', 1086, DB) or 'Bunt's Barrow' from which Bountisborough hundred (Bantesbergahdr', 1168) is named.

Hundreds apparently named from their chief manors are also potentially problematic. In these cases the traditional meeting-place may have been adjacent to or distant from the manorial centre. Anderson, for instance showed that hundreds might bear more than one name, reflecting appurtenance to a central vill on the one hand, and location of meetings on the other, so that being named from a vill does not mean that a hundred also met at that location. ${ }^{37}$ This may be the case with Somborne hundred (Svmbvrne, in Domesday Book, 1086) which was apparently named from the royal manor of King's Somborne, to which it belonged. By the 13th century Somborne was also known as Hundredum de Stokbrygge (1272 Assize Roll). ${ }^{38}$ Stockbridge is $c .4 \mathrm{~km}$ north of

34 John Baker and Stuart Brookes, "Identifying Outdoor Assembly Sites in Early Medieval England" Journal of Field Archaeology 40:1 (2015), 3-21.

35 E.g. III Edmund, clause 2, Hundred Ordinance, and II Cnut, clause 20, in Die Gesetze der Angelsachsen I, ed. Felix Liebermann (Halle, 1903), pp. 190-95 and p. 322; discussed by (among others) H.M. Chadwick, Studies on Anglo-Saxon Institutions (Cambridge, 1905), pp. 239-48; Stenton, Anglo-Saxon England, pp. 292-301; H.R. Loyn, The Governance of Anglo-Saxon England 500-1087 (London, 1984), pp. 140-46.

36 O.S. Anderson, The English Hundred-Names: The South-Western Counties. Lunds Universitets Arsskrift 37.2 (Lund, 1939), pp. 193-94.

37 O.S. Anderson, The English Hundred-Names (Lund, 1934), pp. xxix-xxxi; English HundredNames: The South-Western Counties, 79-80, 83-84, 86-88, 90-91, 92-99.

38 Unless otherwise indicated, forms of names and dates when they are attested as such are from relevant county EPNS volumes or, in Hampshire cases, Richard Coates, The Place Names of Hampshire (London, 1989). 
King's Somborne and seems to have been known as White Somborne in the early Middle Ages, so perhaps the stocc-brycg was the location of the hundredal assemblies. ${ }^{39}$ In support of this identification Stockbridge Down, just $1 \mathrm{~km}$ east of the settlement and inter-visible with it, is the location of a Late Anglo-Saxon execution cemetery lying beside an artificial mound. ${ }^{40}$ This kind of spatial relationship between meeting-places and execution sites is wellknown elsewhere. ${ }^{41}$

The type and location of hundred meeting-places can provide further clues as to the organisation of early administrative territories. It might be assumed that meeting-places should be centrally placed within their district to enable ease of access for all inhabitants. Indeed this is often the case. The aforementioned Evingdale field is an unremarkable location except that it is almost directly at the centre of the hundred it served, lying alongside the Harroway-a significant ancient long-distance routeway that bisects the district. Similarly, the hundred of Kingsclere, though named from a royal manor attested in 9thcentury sources ( $\mathrm{S}_{1507}$ ), apparently held its court at Nothing Hill (presumably from OE $(g e) m \bar{t} t+p i n g+h y l l),{ }^{42}$ a prominent hilltop $2 \mathrm{~km}$ west of the vill, that is central both to the Domesday hundred and the earlier regio of Cleras. ${ }^{43}$

Given this assumption, it is interesting that many meeting-places are actually located on the boundaries between two or more hundreds. The reasons for this might be explained by several different processes (Fig. 13.1):

- A border location, as Margaret Gelling and Aliki Pantos, have previously suggested, might have signified its neutral, liminal position between neighbouring communities, enabling the impartial settlement of local disputes. ${ }^{44}$ They therefore define the limits of neighbouring groups (a), serving as a communal locale—a sort of 'no man's land' — for two or more communities.

- In some cases border meeting-places might have existed in a hierarchy of meeting-places, alongside other local courts (b). Conceivably in this

39 The name 'Stockbridge' itself apparently only came into general use from the early 13th century: Rosalind Hill, "The Manor of Stockbridge," Proceedings of the Hampshire Field Club 30 (1973), 93-101.

40 Andrew Reynolds, Anglo-Saxon Deviant Burial Customs (Oxford, 2009), pp. 120-22.

41 Andrew Reynolds, "Judicial Culture and Social Complexity: A General Model from AngloSaxon England," World Archaeology 45:5 (2014), 699-713.

$42 \quad V C H$ Hants 4, p. 246; Anderson, The English Hundred-Names: The South-Western Counties, p. 194.

43 Eagles, "Small Shires' and Regiones," pp. 131-32.

44 Margaret Gelling, Signposts to the Past (Chichester, 1978); Aliki Pantos, "On the Edge of Things': Boundary Location of Anglo-Saxon Assembly Sites," ASSAH 12 (2003), 38-49, at pp. $43-48$. 
a)

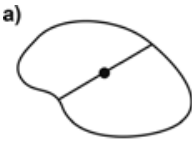

b)

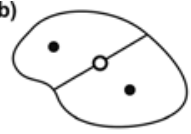

c)

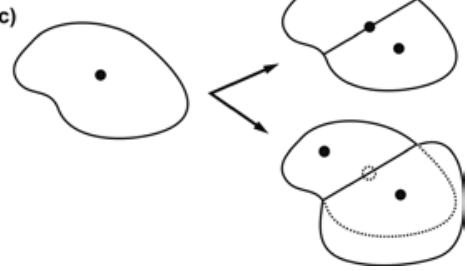

FIGURE 13.1

Theoretical development of meeting-places on district borders

situation border meeting-places were concerned with supra-regional business such as military mobilisation or inter-regional trade, whilst centrally placed meeting-places dealt with more local legal and fiscal matters. ${ }^{45}$

- A third situation could see meeting-places emerge on borders as a result of territorial fission (c). In these instances the earlier meeting-place might have been retained as the court for one of the resulting districts, but was accompanied by a new meeting-place founded more centrally in the neighbouring district. In other cases new meeting-places emerged in the subdivided districts, replacing the earlier court site.

\section{Early Hampshire Territories}

These observations have some relevance to a discussion of the territorial organisation of Hampshire in the Anglo-Saxon period. Hampshire has recently been the subject of an analysis by Bruce Eagles who through detailed retrogressive analysis has suggested a number of early medieval territories predating the Domesday hundredal pattern. ${ }^{46}$ Both Eagles and previous mappings of the

45 Baker and Brookes, "Identifying Outdoor Assembly Sites"; John Baker and Stuart Brookes, "Gateways, Gates, and Gatu: Liminal Spaces at the Centre of Things," in Life on the Edge: Social, Religious and Political Frontiers in Early Medieval Europe, ed. Sarah Semple, Celia Orsini and Sian Mui, Neue Studien zur Sachsenforschung 6 (2017), pp. 253-62; Alexander Langlands, "Ceapmenn and Portmenn: Trade, Exchange, and the Landscape of Early Medieval Wessex," below.

46 Eagles, "Small Shires' and Regiones." It should be stated that Eagles' model is not the only attempt to reconstruct early territories in Hampshire. For an interpretation based on terrain and hydrology, see Eric Klingelhöfer, Manor, Vill and Hundred: The Development of Rural Institutions in Early Medieval Hampshire (Toronto, 1991); for one based on royal estates, see Ryan Lavelle, Royal Estates in Anglo-Saxon Wessex. BAR Brit. Ser. 439 (Oxford, 2007), esp. pp. 37-47. 
Domesday hundreds take as their basis the parish boundaries as documented in the 1851 one-inch Ordnance Survey maps. ${ }^{47}$ By plotting individual placenames rubricated from Domesday Book and other early sources, parishes are then aggregated into larger districts defined by their common boundaries. Fig. 13.2 shows the resulting administrative territories proposed by Eagles and Thorn. ${ }^{48}$ Minor deviations aside, there is a broad correspondence in the alignment of territorial boundaries.

Of the regiones proposed by Eagles, Andeferas and Basingas most closely resemble those of Eastry and Lyminge in Kent in form if not scale. Like the Kentish examples the territories of Andeferas and Basingas are both mirrored by the pattern of Early Anglo-Saxon finds. Early evidence is known from the immediate vicinity of Andover, including settlement finds from Old Down Farm to the south-east of the village of Charlton, $1 \mathrm{~km}$ west of Andover and two 6 th $/ 7$ th-century cemeteries to the west of this in the area of The Portway Industrial Estate. ${ }^{49}$ Basingas is centred on the high-status Early Anglo-Saxon settlement site of Cowdery's Down on the north-west side of the River Loddon and Old Basing, on the eastern bank, its probable 8th-century successor. ${ }^{50}$ Both Andover and Basing were royal vills in Domesday Book, giving their names also to their hundreds, preserving an early function as tribute centres and royal accommodation. However, both are considerably smaller than their Kentish counterparts. As reconstructed by Eagles they are only $215^{-280 ~ s q . ~ k m . ~}$ The analogy with Kent suggests that these regiones were essential elements of a larger political entity, not autonomous units.

These two putative regiones can be contrasted with the much larger provincia of the Meonware mentioned by Bede. Named from the River Meon, this district comprises two main concentrations of Early Anglo-Saxon burials, along the Meon valley in the north, and stretched along the scarp of Ports Down in the south. All the Domesday hundreds making up this regionMeonstoke, East Meon, Chalton, Titchfield, Ports Down, Bosbarrow, and

47 F.R. Thorn, "Hundreds and Wapentakes," in The Hampshire Domesday, ed. Ann Williams and R.W.H. Erskine (London, 1989), pp. 28-39.

48 Eagles, "Small Shires' and Regiones"; Thorn, "Hundreds and Wapentakes."

49 David Hopkins, Hampshire and the Isle of Wight Extensive Urban Survey: Andover (Winchester, 2004), p. $3<$ http://archaeologydataservice.ac.uk/archiveDS/archiveDownload?t $=$ arch-378-1/dissemination $/$ pdf/test_valley/andover/assessment/andover_assessment. pdf $>$ (accessed Jan. 2018).

5o Martin Millet and Simon James, "Excavations at Cowdery's Down, Basingstoke, Hampshire, 1978-81," Archaeological Journal 140 (1983), 151-279; David Hopkins, Hampshire and the Isle of Wight Extensive Urban Survey: Basingstoke (Winchester, 2004), p. $2<$ http://archaeologydataservice.ac.uk/archiveDS/archiveDownload?t=arch-378-1/dissemination/ pdf/test_valley/andover/assessment/andover_assessment.pdf> (accessed Jan. 2018). 


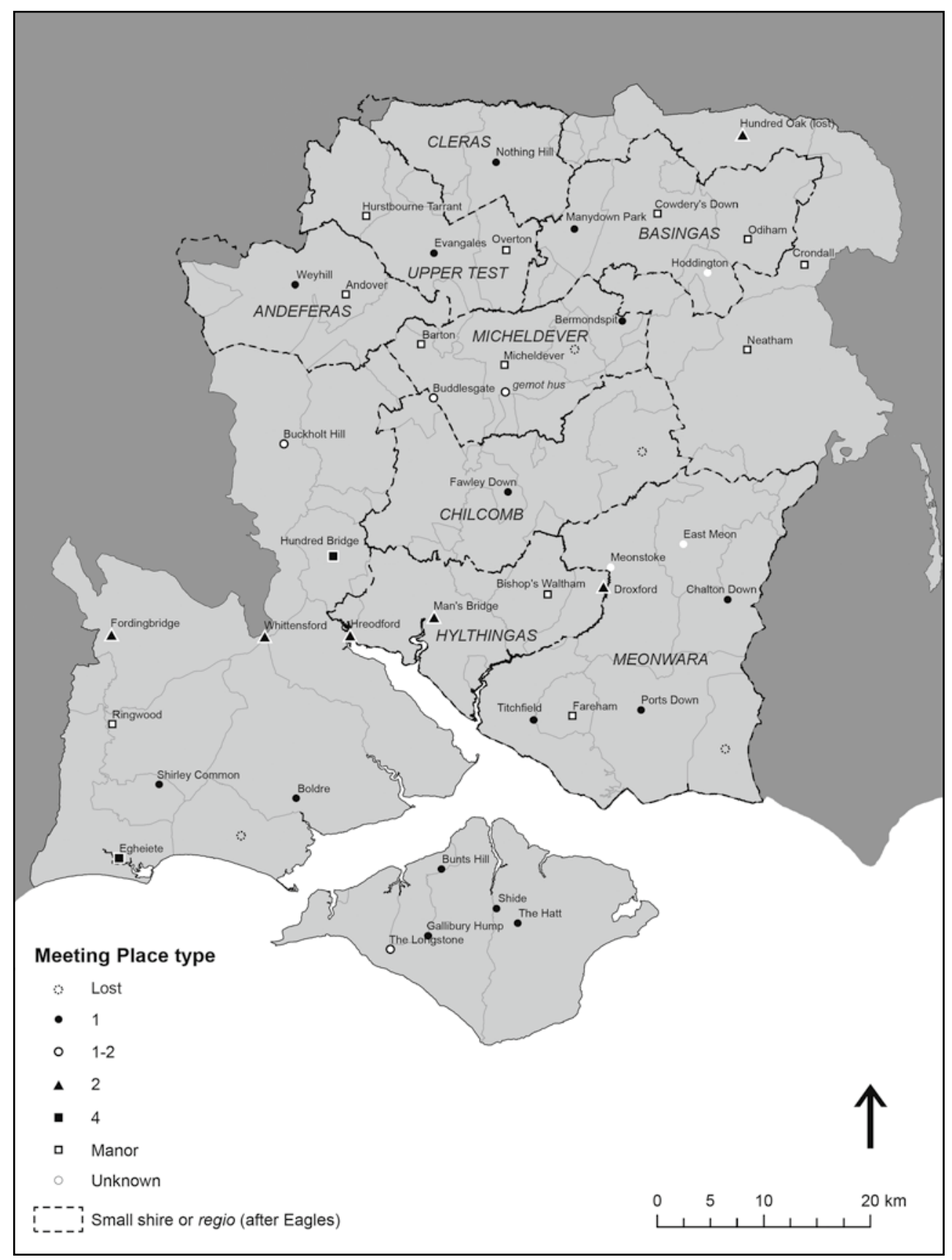

FIGURE 13.2 Small shires and regiones of Hampshire, shown alongside the Domesday hundreds and their meeting-places 
probably Fareham - are named from topographical features rather than manors, and the district notably lacks central places of the types found in the other core Hampshire territories. The more dispersed character of settlement in this regio, the different development of its hundreds, and its much discussed associations with a 'Jutish' settlement, argue for an alternative origin as a selfcontained district. It may also once have been larger: place-names indicating a Jutish association are found also further west at Ytene in the New Forest and Bishopstoke (Ytingstoc) on the River Itchen. ${ }^{51}$

Further understanding of the organisation of the regiones can be gained from the location of hundred meeting-places recorded in Domesday Book (Fig. 13.2). Several observations can be made of this plot. Firstly, the distribution of different types of meeting-places appears to corroborate the pattern of regiones identified by Eagles. Each regio has at its centre either an important estate centre, or a meeting-place of Type 1: elevated, often on undifferentiated upland, natural eminences, and/or common land. Evangales (Upper Test regio), Nothing Hill (Cleras), Fawley Down (Chilcomb) are all examples of Type 1 meeting-places, and in each case it is likely that the Domesday hundred court continued an assembly tradition from earlier times. This pattern may be more pronounced. The regio of Andeferas, though centred on a royal vill, apparently had a meeting-place for the 'out hundred' at Weyhill, a Type 1 site $6 \mathrm{~km}$ west of Andover. ${ }^{52}$ The bounds of Micheldever ( $\mathrm{S}_{360}$ ) mention a gemot hus (OE (ge) $m \bar{t}$ ' 'assembly', hüs 'house'), which Brooks identifies as lying on the crossroads of the Roman road from Winchester to Silchester (Margary 42a), and Alresford drove (SU 5148736386 ). ${ }^{53}$ This finding is very akin to what is seen in Kent, where the lathes similarly met at places at a remove from their central vills. Thus Limen lathe assembled not at the royal vill of Lyminge, but at Shipway

$5^{1} \quad$ Barbara Yorke, "The Jutes of Hampshire and Wight and the Origins of Wessex," in AngloSaxon Kingdoms, ed. Bassett, pp. 84-96, at pp. 89-92; but see this volume: John Baker and Jayne Carroll, "The Afterlives of Bede's Tribal Names in English Place-Names," above. There are indications that this regio survived in part as a large royal estate that was consistently pulled back into royal control in the 9th-11th centuries: Lavelle, Royal Estates, pp. 93-95.

52 Eagles, "Small Shires' and Regiones," p. 131. Also of possible significance it the putative location of the royal assemblies of Grateley $(c .925 \times 30)$ and Enham (1008) at Quarley Hill, $10 \mathrm{~km}$ south-west of Andover: Ryan Lavelle, "Why Grateley? Reflections on Anglo-Saxon Kingship in a Hampshire Landscape," PHFCAS 60 (2005), 154-169. While royal assemblies did not generally take place at the same locations as later hundredal meeting places, it may be that they relate in some way to the assembly places of earlier regiones.

53 N.P. Brooks, "The Oldest Document in the College Archives? The Micheldever Forgery," in Winchester College: Sixth-Centenary Studies, ed. Roger Custance (Oxford, 1982), pp. 189-228; Brooks, "Alfredian Government: the West Saxon Inheritance," in Alfred the Great: Papers from the Eleventh-Centenary Conferences, ed. Timothy Reuter (Aldershot, 2003), pp. 153-174. 
Cross in Lympne, some $7 \mathrm{~km}$ to the south-west, whilst those of Eastry lathe assembled at the Type 1 site of Eastling (formerly Haddling) Wood in Northbourne, $6 \mathrm{~km}$ to the south of Eastry. ${ }^{54}$

Secondly, it would seem that the fragmentation of regiones into smaller administrative territories saw the creation in many cases of hundreds centred and named from important estate centres. This development has been well attested elsewhere, and would seem to reflect a process whereby labour and other services devolved from kings to thegns and ecclesiastical communities whose estates formed the core of Domesday hundreds. ${ }^{55}$ By the time of the Domesday survey, the regio of Andeferas consisted of the hundreds of Andover, based on the royal vill, and Welford. The latter hundred and all its manors belonged to the abbess of Wherwell by TRE. Basingas by comparison consisted by the Domesday survey of the royal estate-hundreds of Basingstoke and Odiham, as well as the hundreds of Chutely (named after a Type 1 meeting-place in Upper and Lower Chitterling fields, south of Manydown Park and close to the later meeting-place of the hundred 'under a hedge at Malshanger'), ${ }^{56}$ and Hoddington (OE pers.n. * $H \bar{o} d(d)(a)+i n g a+t \bar{u} n$ 'farm/settlement of Hodda's people'), possibly named after a local thegn. A similar process potentially underpinned the creation of a private hundred, described in the forged Micheldever charter ( $\mathrm{S} 360)$, out of a larger earlier regio including the territory of Micheldever, Bountisborough, Mainsborough, Barton and Bermondspit. ${ }^{57}$

Thirdly, it is potentially significant that the locations of later hundredal meeting-places named from bridges/fords are largely confined to the putative scir of Hylthingas and the New Forest. Audrey Meaney considered such meeting-places to belong to the earliest stratum of territorial formation, butfollowing the arguments about border meeting-places above- this need not necessarily be the case. ${ }^{58}$ Three of the four Domesday hundreds comprising the scir of Hylthingas are named from bridges/fords: Droxford (drocenesforda 826 (12th)), ${ }^{59}$ Redbridge ((of) Hreodbrycge 956), ${ }^{60}$ and Mansbridge (Mannes

54 Cullen, "The Place-Names," 1:289.

55 e.g. Blair, "Frithuwold's kingdom."

56 VCH Hants 4, p. 223.

57 Brooks "Oldest Document"; Eagles, "Small Shires' and Regiones."

$5^{8}$ Audrey Meaney, "Gazetteer of Hundred and Wapentake Meeting-Places of the Cambridgeshire Region," Proceedings of the Cambridge Antiquarian Society 82 (1993), 67-92; Meaney, "Hundred Meeting-Places In the Cambridge Region," in Names, Places and People: An Onomastic Miscellany in Memory of John McNeal Dodgson, ed. A.R. Rumble and A.D. Mills (Stamford, 1997), pp. 195-240.

$59 \quad \mathrm{~S} 275$

6o S 636. Hreodbrycge is normally thought to be Hreutford in Bede HE iv, 16; Lavelle Royal Estates, p. 39. On the semantic uses of $\mathrm{OE}$ brycg and ford see particularly the discussion by John Baker and Stuart Brookes, Beyond the Burghal Hidage (Leiden, 2013), pp. 164-67. 
brycge $\left.93^{2}\left(15^{\text {th }}\right)\right) ;{ }^{61}$ the former two lying on the eastern and western limits of the district, and the borders of its Domesday successors. The regularity of this arrangement, the similarity in places chosen as later meeting-places on border river-crossings, and the divergence in naming practices from other regiones in Hampshire, all hint at the artificial nature of this scir, and its imposition into an earlier territorial arrangement. Eagles $(2015,129)$ is surely correct to see the creation of this scir as part of the process by which the emporium of Hamwic was dominated by West Saxon kings in the 7th century, but these differences would also suggest that it belongs to a different chronological horizon than the other regiones.

In this regard it may be significant that the only other river-crossing meetingplaces in Hampshire, Fordingbridge (Forde 1086 DB) and the enigmatic Wittensford (Whittensford 1670, '?Witan + ford'), are both located on or very close to the shire boundary between Hampshire and Wiltshire. Based purely on the typology of meeting-places, the creation of a scir of Hylthingas may be contemporaneous to the formalisation of territories at this larger scale. Perhaps further evidence of this is the location of place-names compounded with scir: Shirrell Heath in Shedfield, and Shirley in Sople, both of which lie outside the region of core shires described by Eagles.

\section{Territory Formation in Early Medieval Hampshire}

Despite the burgeoning interest in early medieval territories questions remain about the extents to which they reflected a form of community identity, and where on a sliding scale of autonomy these identities originated. Both are very difficult to answer because they raise fundamental questions about the nature of early medieval power and how it was rooted in local communities. While the observations made by James Campbell on this matter remain apposite, the evidence from Hampshire introduces some additional dimensions.

A general consensus amongst historians is that early medieval kingship was predicated to a great degree on politics of consensus-power resided in and drew from, the group over which it was exercised. ${ }^{62}$ In small-scale societies, rule is embedded in local social structures, personal relationships, and

\footnotetext{
$61 \quad S_{418}$

62 e.g. Talcott Parsons, "On the Concept of Political Power," Proceedings of the American Philosophical Society 107 (1963), 232-62; Michael Mann, The Sources of Social Power: Volume 1, A History of Power from the Beginning to $A D 1760$ (Cambridge, 1986); T. Reuter, "Assembly Politics in Western Europe from the Eighth Century to the Twelfth," in The Medieval World, ed. Peter Linehan, and Janet Nelson (London, 2001), pp. 432-50.
} 
community dynamics, so that authority resides in the consensus that forms and legitimises the existence of a political centre. ${ }^{63}$ The expectation is therefore that the origins of early medieval political communities are most likely to be found in the patterns of 'stakeholders' visible in the $5^{\text {th }}$ and 6 th centuries.

From this perspective, amongst the more persuasive models of communityterritory formation are those that have taken an explicitly cultural ecological approach. The 'river and wold' model, espoused, amongst others, by Alan Everitt and Tom Williamson argues that the natural environment has an important structuring effect on the formation of early territories. ${ }^{64}$ Thus, there is often a tendency for these territories to conform to the basins of river systems, with boundaries collinear with those of the watershed. ${ }^{65}$ These 'drainage provinces' naturally comprised variations in drainage, soils, relief and landcover that lent themselves to particular forms of agricultural activity and settlement. Where underlying soils are free-draining, such as on gravel terraces, the sides of river valleys are commonly the most suitable for arable agriculture, while intervening uplands — the 'wold' — often comprises less fertile, thinner, and exposed lands, better suited to woodland management and animal husbandry. ${ }^{66}$ Thus, communities developed within drainage provinces principally as a result of interactions governed by agriculture and livestock farming. The lordships that existed over these communities were correspondingly 'extensive', drawing on services and renders that spanned these ecological zones. ${ }^{67}$

While Hampshire does not have the clearly differentiated landscape of Kent - from which Alan Everitt first developed the 'river and wold' modelthere are some areas where it may be usefully applied. Work undertaken by the UCL Beneath the Tribal Hidage project - another project with which Barbara was heavily involved-has described the clear tendency for early Anglo-Saxon burial sites to be associated with soils of fertility 3 and above, that were also free draining. ${ }^{68}$ In Hampshire these soils mainly restrict themselves to the distinctive

63 Julio Escalona, Orri Vésteinsson and Stuart Brookes, "Polities, Neighbourhoods and Things In-between," in Polity and Neighbourhood in Early Medieval Europe, ed. Escalona, Vésteinsson, and Brookes (Turnhout, 2019), pp. 11-38.

64 Alan Everitt, "River and Wold: Reflections on the Historical Origin of Regions and Pays," Journal of Historical Geography 3 (1977), 1-19; Everitt, Continuity and Colonization: the Evolution of Kentish Settlement (Leicester, 1986); e.g. Tom Williamson, Environment, Society and Landscape in Early Medieval England (Woodbridge, 2013).

65 Williamson, Environment, Society and Landscape, pp. 82-106.

66 Williamson, Environment, Society and Landscape, p. 55

67 On this point cf. also Rosamond Faith, The English Peasantry and the Growth of Lordship (London, 1997), pp. 1-14.

68 Sue Harrington and Martin Welch, The Early Anglo-Saxon Kingdoms of Southern Britain AD 450-65o: Beneath the Tribal Hidage (Oxford, 2014), p. 91; cf. also Wendy Davies and 
Upper Chalk band running east-west across the county, and this same area is also the focus of $5^{\text {th- }}$ and 6th-century burial (Fig. 13.3). North and south of this band heavier Tertiary clays and sandy soils predominate. Here, three noteworthy clusters of burials are associated with smaller pockets of free-draining soils: across the centre of the Isle of Wight, the upper reaches of the River Avon, and a string of burials along Portsdown. Each in its own way may be regarded as an area of early high-status expression, with indications of connections with Kent. ${ }^{69}$

In the main zone of good quality free-draining soils, the tendency to form a river valley territory is most clearly expressed in Chilcomb regio, the boundaries of which conform almost precisely to the upper watershed of the River Itchen. In what became the regio 6th-century burials cluster around Winchester with others at Tichborne Down House and Cheriton on tributaries of the Itchen. ${ }^{70}$ Similar river-based territories can be reconstructed focusing on the Rivers Anton and Dever, which became the regiones of Andeferas and Micheldever respectively. ${ }^{71}$ By contrast, neither the aforementioned River Avon complex, nor one based on the River Meon survived as recognisable administrative districts. ${ }^{72}$

Hayo Vierck, "The Contexts of Tribal Hidage: Social Aggregates and Settlement Patterns," Frühmittelalterliche Studien 8 (1974), 223-93.

69 C.J. Arnold, The Anglo-Saxon Cemeteries of the Isle of Wight (London, 1982); D.A. Hinton and Sally Worrell, "An Early Anglo-Saxon Cemetery and Archaeological Survey at Breamore, Hampshire, 1999-2006," Archaeological Journal 174 (2017), 68-145; Stuart Brookes, "Folk' Cemeteries, Assembly and Territorial Geography in Early Anglo-Saxon England," in Power and Place in Europe in the Early Middle Ages, ed. Jayne Carroll, Andrew Reynolds and Barbara Yorke (London, 2019), pp. 64-90.

70 Martin Biddle has argued that the core of this regio, formed of the monastic estate of Chilcomb, was already defined, and probably in royal possession, before the mid-7th century: "Hampshire and the Origins of Wessex," in Problems in Economic and Social Archaeology, ed. G. Sieveking, I.H. Longworth and K.E. Wilson (London, 1976), pp. 323-42, at p. 335 .

71 Somewhat different river-based territories have been reconstructed by Klingelhöfer, Manor, Vill and Hundred; however, these are considerably smaller units that subdivide river basins into a series of 'archaic hundreds'. It is hard to reconcile these conjectural territories with the regio of Micheldever as reconstructed by Brooks, "Alfredian Government," p. 172, or the regiones discussed by Eagles, "Small Shires' and Regiones," even if the broad observations regarding settlement evolution are correct.

72 Although it is not based on a river valley, Barry Cunnliffe's reconstruction of Ceptune Hundred in the area of the Meonwara, similarly conforms almost precisely with the watershed boundaries of the minor rivers Hermitage and Lavant, but does not appear to be fossilised as a 'small shire': "Saxon and Medieval Settlement Pattern in the Region of Chalton, Hampshire," Medieval Archaeology 16 (1972), 1-12. 


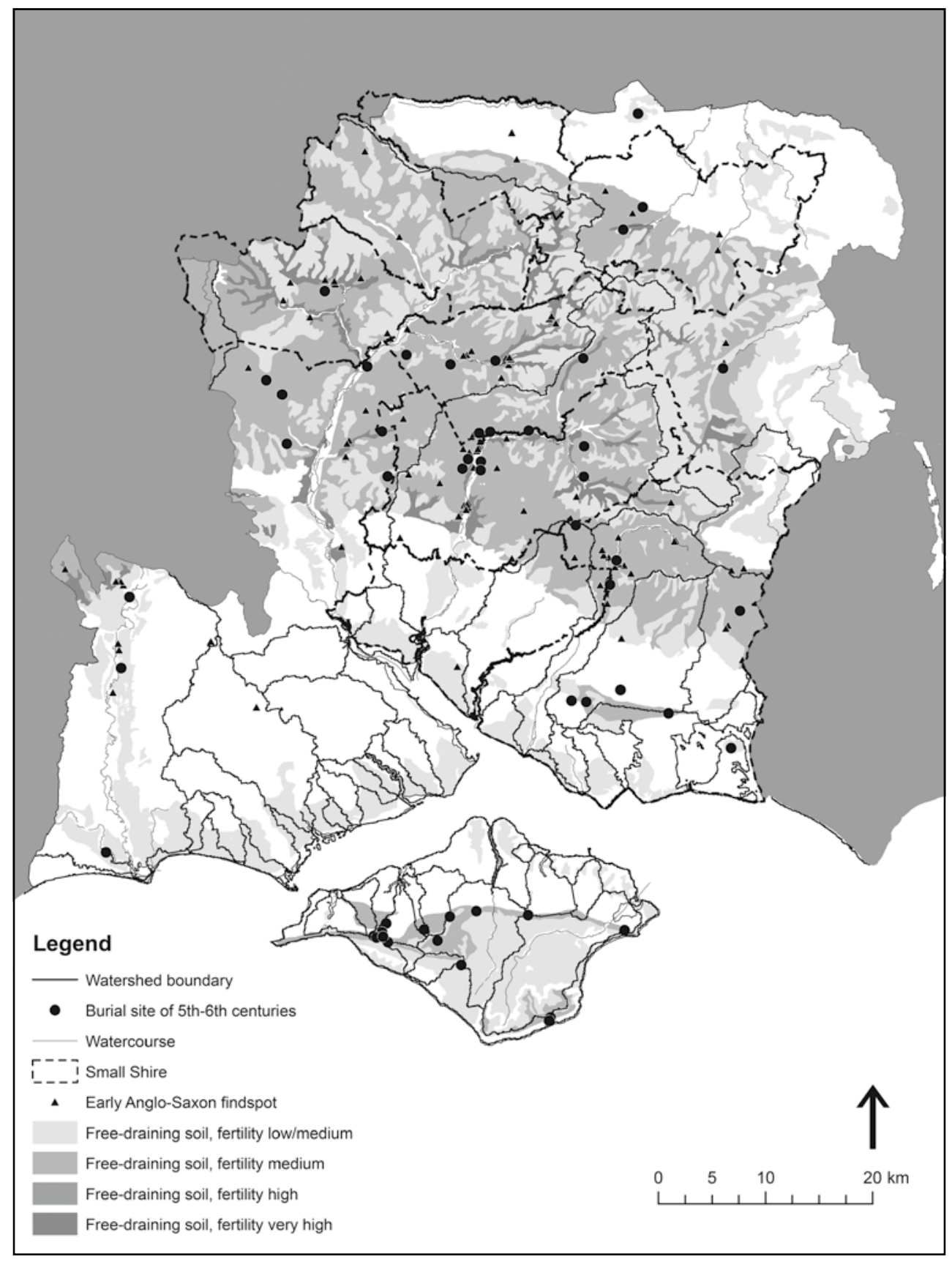

FIGURE 13.3 Early Anglo-Saxon burials of the $5^{\text {th }}$ and 6th centuries in Hampshire shown against the distribution of free-draining soils, after: Harrington and Welch, Early Anglo-Saxon Kingdoms 
However, while the 'river and wold' model might work reasonably well in certain parts of Hampshire, the evidence makes it more difficult to apply in others. Early burial sites, settlements, and putative territories in the north-west of the county bear little resemblance to drainage regions, and here it seems likely that other processes of community identity were at play. In its ecological composition, the Upper Test with its fertile well-drained soils and broad valley contours is identical to those of the Anton and Dever, but so far there is virtually no evidence for $5^{\text {th- }}$ or 6 th-century settlement. North of this, in what became Cleras, both appropriate soils and archaeological indicators for early settlement are hard to come by. On these grounds it seems highly unlikely that either was constituted as a recognisable territory before the 7 th century. As late as the 18th century the parishes comprising this part of Hampshire consisted of large tracts of common and open land. ${ }^{73}$ Indeed, the high numbers of swine renders recorded for the Upper Test in Domesday Book at, for example, Whitnal, Whitchurch, and Overton, suggest that this region-despite the availability of good quality soils - was still only partially cultivated as late as the 11th century, with many settlements there perhaps only occupied on a temporary or seasonal basis before that.

Taken in these broad terms there is clearly some variability between these putative territories. Some consistently hold to a certain structural appearance, sharing an ecological profile, focusing on a cluster of 5 th- to 6th-century burials, and an administrative configuration attuned to relief and-in later attested meeting-places - topographical features. But not all districts sharing this profile emerged intact as later 'small shires' as might be supposed by Bassett's knock-out model. Rather, domination over these communities involved the refashioning of territorial arrangements in a seemingly artificial manner. Hylthingas-scir as reconstructed by Eagles bears little resemblance to a drainage province-there are virtually none of the soils favoured by early settlement and archaeological evidence is noticeably thin before the 7 th century. Coupled with the differences in the form of its meeting-places it seems likely that it was inserted into, rather than developed organically from, the networks of communities within it. In a similar fashion the lack of archaeological evidence and the divergence in ecological profile of north-west Hampshire argue against their origins as coherent 'folk' territories of the early Anglo-Saxon period. Here, it seems more likely that territory formation came as a result of administrative measures. However, the similarity of their meeting-places and the scale and form of these districts to those of 'core' regiones suggests that these emerged at a different time or via different processes than Hylthingas-scir. Of

73 John Chapman and Sylvia Seeliger, A Guide to Enclosure in Hampshire (Winchester, 1997). 
potential interest in this regard is the observation made by Margaret Gelling, and discussed further by Barbara and others, that the morphology of Hampshire's northern boundary appears artificial rather than naturally defined by terrain, perhaps reflecting its origin as a border imposed during a period of Mercian domination in the late 7 th or 8 th centuries. ${ }^{74}$

One possible reason for the different temporal scale of territorial development is that soils and landcover in north-west (as perhaps south-west and south-east) Hampshire favoured livestock over arable farming with concomitant effects on the nature of the communities living there. It may be significant that in the north the regiones of Andeferas, Basingas, and Cleras were all centred on royal vills for whom the extraction of pastoral resources was priority. In this respect the ceapmanna dele discussed by Alex Langlands (this volume) takes on additional relevance.

Whatever the precise chronology and mechanisms of territory formation in early England, the evidence from Hampshire demonstrates that this was a constant and evolving process. Land management, community identity, and administrative innovations drove the formation of successive territories that could preserve or radically change through time. Reconstruction of these early territories requires the careful triangulation of a variety of sources spanning ecology, geography, place-name research, archaeology and history. The result is a picture of significant diversity and dynamism in the early medieval landscape.

74 Margaret Gelling, Place-Names of Berkshire, 3 (Cambridge, 1976), pp. 844-5; Yorke, Wessex, pp. 88-89; Andrew Reynolds and Alexander Langlands, "Social Identities on the MacroScale: a Maximum View of Wansdyke," in People and Space in the Middle Ages, ed. Davies, Halsall, and Reynolds, pp. 13-44. 